\title{
EVALUATION OF THE DAIRY COWS' WELFARE BASED ON THE RESULTS OF THE PROTOCOL OF THE COORDINATED VETERINARY INSPECTION PROGRAM IN PODKARPACKIE VOIVODESHIP
}

\author{
Edyta Bauer $^{\mathrm{a}^{*}}$, Justyna Żychlińska-Buczek ${ }^{\mathrm{a}}$, Anna Karbowniczak ${ }^{\mathrm{b}}$, Hubert Latała $^{\mathrm{b}}$ \\ ${ }^{\text {a }}$ Department of Genetics and Animal Breeding, University of Agriculture in Krakow \\ ${ }^{\mathrm{b}}$ Institute of Agricultural Engineering and Informatics, University of Agriculture in Krakow \\ "Corresponding author: e-mail: e.bauer@ur.krakow.pl
}

\begin{tabular}{|c|c|}
\hline ARTICLE INFO & ABSTRACT \\
\hline $\begin{array}{l}\text { Article history: } \\
\text { Received: December } 2016 \\
\text { Received in the revised form: } \\
\text { January } 2017 \\
\text { Accepted: March } 2017\end{array}$ & $\begin{array}{l}\text { Dairy cows production plays a significant role in development of } \\
\text { Podkarpackie Voivodeship. Progress in this production branch may } \\
\text { depend on the dairy production support which is given after relevant } \\
\text { types of actions are undertaken. The objective of the research was to } \\
\text { determine changes in the level of welfare of production animals, }\end{array}$ \\
\hline $\begin{array}{l}\text { Key words: } \\
\text { milk production, } \\
\text { Podkarpackie Voivodeship, } \\
\text { Veterinary protocol of the Coordinated } \\
\text { Veterinary Inspection Program, } \\
\text { welfare }\end{array}$ & $\begin{array}{l}\text { evaluation of practice in dairy cows breeding in the province of } \\
\text { Ropczyce and Sędziszów. Breeding documentation and control proto- } \\
\text { cols of the Coordinated Veterinary Inspection Program were applied } \\
\text { pursuant to the resolution ( } 1 \text { ) of the Minister of Agriculture and Rural } \\
\text { Development of } 28 \text { June } 2010 \text { on minimal conditions of maintaining } \\
\text { farm animal species. } 10 \text { production herds of dairy cows (n-240) and } \\
\text { heifers }(n=101) \text { which produce } \geq 10200 \text { kilo of milk per lactation were } \\
\text { used to achieve this objective. Dairy production was observed during } \\
\text { individual visits in farms. Surveys were carried out with farm employ- } \\
\text { ees with the use of properly prepared veterinary control protocols of } \\
\text { the Coordinated Veterinary Inspection Program. Control results were } \\
\text { obtained based on the respondents' opinion from controlling institu- } \\
\text { tions, such as: The Agency for Restructuring and Modernization of } \\
\text { Agriculture, Regional Veterinary Office and similar certified bodies. }\end{array}$ \\
\hline
\end{tabular}

\section{Introduction}

Demand for dairy products is shaped by consumers who want cheap and safe products of high quality produced with the use of relevant management practices (Rollin, 2004; Fulwider et al., 2008; Sapp et al., 2009). The issues related to maintenance of the animal welfare, including dairy cows are one of the priorities of ensuring the so-called food safety (Adamczyk and Gill, 2014). Provisions of the food industry oblige not only producers but also cattle breeders. The staff which take care of animals must have indispensable knowledge on the health and animal needs related to ensuring relevant welfare. Thus, it is crucial to choose such a system which will satisfy the basic animal needs, mainly with regard to feeding, access to water, indispensable life space, ensuring the company of other animals, hygiene of maintenance, treatment, micro-climate of premises and lighting condi- 
tions. In the breeding practice, checking whether the principles of dairy cow welfare are complied with, takes place through assessment of the animals' longevity including the analysis of the reasons for culling. It is measurably translated into profitability of milk production and is included in the breeding work (Adamczyk et al., 2013 a; Ziętara, 2013; Jagusiak et al., 2014). Thus, more attention is paid to the possibility of systematic monitoring of dairy cows welfare, in particular of highly efficient cows within the period of their use.

Milk production and dairy cows breeding in Podkarpackie Voivodeship may be a basis of its competitiveness. Development of dairy production may prove to be a domain of regions with a low level of industrialization, which has a great acreage of $\mathrm{AL}$ which is necessary to breed animals in production farms. Technology and production tradition is an additional factor in milk production. On the other hand, development of the agricultural zone in milk production is related to realization of various forms and principles for agriculture and food producers. Development of this agricultural sector depends on the conditions resulting from various types of institutions and organizations which support farmers. Among institutions which constitute an important element in development of dairy cattle breeding there is the Ministry of Agriculture and Rural Development, Office for Protection of Consumers and Competitiveness and the State Veterinary Inspection (Resolution 2).

In this paper, the objective was to indicate the introduced changes in the improvement of the welfare and care over animals in the selected farms, according to a new legal procedure for dairy farms in Podkarpackie Voivodeship. Breeding documentation of farms and control protocols of the Coordinated Veterinary Inspection Program were applied pursuant to the resolution (1) of the Minister of Agriculture and Rural Development of 28 June 2010 on minimal conditions of maintaining farm animal species.

The analysis was carried out with regard to the indication of Podkarpackie Voivodeship as a region suitable for development of dairy production.

\section{Material and methods}

The research was carried out in 2008-2013 in ten farms which deal with dairy production in Podkarpackie Voivodeship. This research was carried out as a part of the development of agricultural production in this region.

The list of certified milk producers, whose herds are controlled on account of the dairy utility, came from the Ministry of Agriculture and Administration (2008). Production farms from the certified list were previously divided into categories, on account of the production size or the number of inspections which were carried out there. Ten visits were carried out within the municipality in the selected dairy farms. Visitations included a questionnaire in a farm, with the use of breeding information concerning animals, the so - called, heifer's cow's card. The prepared protocols included numerous questions concerning the characteristics of maintenance of animals, records of sick animals, type of used medicines, size and lighting of premises, which enabled evaluation of the conditions of the dairy production 
Evaluation of the dairy...

development. The research included farms which use a varied maintenance system (loose housing, stanchion-tied stable), care and handling with animals and requirements concerning livestock (LSU per $\mathrm{m}^{2}$ ), space (height of buildings) fodder system, keeping indispensable breeding documentation.

\section{Results}

Research results concerning milk production in a varied maintenance, animal care and handling, covered entire herds $(n=341)$ in the period of lactation of cows. Each single farm and particular herds were subjected to observations. Among the surveyed milk producers, $100 \%$ claimed that profitability of agricultural production is satisfactory and enables to maintain its continuity. Table 1 presents the condition of the livestock of cows and heifers in the observed dairy farms.

Table 1.

Livestock in the researched farms

\begin{tabular}{lcc}
\hline Herd & Cows & Heifers \\
\hline I & 30 & 14 \\
II & 26 & 11 \\
III & 22 & 8 \\
IV & 14 & 5 \\
V & 17 & 7 \\
VI & 35 & 16 \\
VII & 25 & 10 \\
VIII & 28 & 15 \\
IX & 16 & 8 \\
X & 27 & 7 \\
\hline TOTAL & 240 & TOTAL \\
\hline & & Source: Regional Veterinary Inspectorate in Ropczyce
\end{tabular}

Analysis of animals' welfare in dairy farms was presented in the form of control protocols. Control criteria were included in the form of tables. A positive control was marked as "P", negative as "N", whereas "-" means that no control was made in a given farm in a given year. A proper grade was given at the evaluation of the required criterion in a form.

Results which were not documented previously from $50 \%$ of production farms (Table 2 ) were supplemented after the research was carried out and after animals were treated.

During visits, vets were not obliged to issue certificates on past diseases of animals in production farms. This situation has not changed after 2010 when the Veterinary Inspection obliged doctors and farmers to keep medical documentation for animals in a farm.

Tables 3 and 4 present data concerning the conditions of animal maintenance and care in the investigated farms for 2008-2013. 
E. Bauer, J. Żychlińska-Buczek, A. Karbowniczak, H. Latała

Table 2 .

Record of treatment and prohibition of storing and using medical substances in 2008-2013

\begin{tabular}{lcccccccccccc}
\hline Year & \multicolumn{2}{c}{2008} & & 2009 & & 2010 & & 2011 & & 2012 & & 2013 \\
Criteria/ & A & & & & & & & & & & \\
Farm & & & & & & & & & & & & \\
I & $\mathrm{N}$ & $\mathrm{P}$ & - & - & $\mathrm{P}$ & - & - & $\mathrm{P}$ & - & $\mathrm{P}$ & $\mathrm{N}$ & - \\
II & - & - & $\mathrm{P}$ & - & $\mathrm{N}$ & - & - & $\mathrm{N}$ & - & $\mathrm{P}$ & $\mathrm{P}$ & - \\
III & - & - & - & $\mathrm{P}$ & - & $\mathrm{P}$ & $\mathrm{P}$ & - & - & - & - & $\mathrm{P}$ \\
IV & - & $\mathrm{N}$ & $\mathrm{P}$ & - & $\mathrm{P}$ & - & - & $\mathrm{P}$ & - & - & $\mathrm{P}$ & $\mathrm{P}$ \\
V & - & $\mathrm{P}$ & - & $\mathrm{P}$ & $\mathrm{N}$ & $\mathrm{P}$ & - & - & - & $\mathrm{P}$ & $\mathrm{P}$ & - \\
VI & - & - & - & - & $\mathrm{P}$ & - & - & $\mathrm{P}$ & - & $\mathrm{P}$ & $\mathrm{N}$ & - \\
VII & - & - & $\mathrm{P}$ & - & $\mathrm{P}$ & - & - & $\mathrm{P}$ & - & $\mathrm{P}$ & $\mathrm{P}$ & - \\
VIII & - & - & - & $\mathrm{P}$ & - & $\mathrm{P}$ & $\mathrm{P}$ & - & - & - & - & $\mathrm{P}$ \\
IX & $\mathrm{P}$ & - & $\mathrm{P}$ & - & $\mathrm{P}$ & - & - & $\mathrm{P}$ & - & - & $\mathrm{P}$ & $\mathrm{P}$ \\
$\mathrm{X}$ & $\mathrm{P}$ & - & - & $\mathrm{P}$ & $\mathrm{P}$ & $\mathrm{P}$ & - & - & - & $\mathrm{P}$ & $\mathrm{P}$ & - \\
\hline
\end{tabular}

Legend: A - record of treatment; $\mathrm{B}$ - storing of prohibited medicines

Source: Regional Veterinary Inspectorate in Ropczyce

Table 3.

Care, freedom of movement, lighting in a shed 2008-2010

\begin{tabular}{|c|c|c|c|c|c|c|c|c|c|}
\hline Year & 2008 & & & & 2009 & & & 010 & \\
\hline Criteria / farm & A & B & $\mathrm{C}$ & A & B & $\mathrm{C}$ & A & B & $\mathrm{C}$ \\
\hline \multicolumn{10}{|l|}{ I } \\
\hline II & $\mathrm{P}$ & $\mathrm{P}$ & $\mathrm{N}$ & - & - & - & $\mathrm{P}$ & $\mathrm{P}$ & $\mathrm{P}$ \\
\hline III & - & - & - & - & - & - & - & - & - \\
\hline IV & - & - & - & $\mathrm{P}$ & $\mathrm{P}$ & $\mathrm{P}$ & $\mathrm{P}$ & $\mathrm{P}$ & $\mathrm{P}$ \\
\hline V & - & - & - & - & - & - & - & - & - \\
\hline VI & - & - & - & - & - & - & - & - & - \\
\hline VII & - & - & - & $\mathrm{P}$ & $\mathrm{P}$ & $\mathrm{P}$ & $\mathrm{P}$ & $\mathrm{P}$ & $\mathrm{P}$ \\
\hline VIII & $\mathrm{P}$ & $\mathrm{P}$ & $\mathrm{N}$ & $\mathrm{P}$ & $\mathrm{P}$ & $\mathrm{P}$ & $\mathrm{P}$ & $\mathrm{P}$ & $\mathrm{P}$ \\
\hline IX & - & - & - & - & - & - & - & - & - \\
\hline \multirow[t]{2}{*}{$X$} & $\mathrm{P}$ & $\mathrm{P}$ & $\mathrm{P}$ & - & - & - & $\mathrm{P}$ & $\mathrm{P}$ & $\mathrm{P}$ \\
\hline & - & - & - & $\mathrm{P}$ & $\mathrm{P}$ & $\mathrm{P}$ & $\mathrm{P}$ & $\mathrm{P}$ & $\mathrm{P}$ \\
\hline
\end{tabular}

Source: Regional Veterinary Inspectorate in Ropczyce 
Evaluation of the dairy...

Table 4.

Care, freedom of movement, lighting in a shed 2011-2013

\begin{tabular}{|c|c|c|c|c|c|c|c|c|c|}
\hline \multirow{2}{*}{$\begin{array}{l}\text { Year } \\
\text { Criteria / farm }\end{array}$} & \multicolumn{3}{|c|}{2011} & \multicolumn{3}{|c|}{2012} & \multicolumn{3}{|c|}{2013} \\
\hline & A & B & $\mathrm{C}$ & A & B & $\mathrm{C}$ & A & B & $\mathrm{C}$ \\
\hline I & - & - & - & - & - & - & $P$ & $P$ & $P$ \\
\hline II & $\mathrm{P}$ & $\mathrm{P}$ & $\mathrm{P}$ & $\mathrm{P}$ & $\mathrm{P}$ & $\mathrm{P}$ & - & - & - \\
\hline III & - & - & - & - & - & - & $\mathrm{P}$ & $\mathrm{P}$ & $\mathrm{P}$ \\
\hline IV & $\mathrm{P}$ & $\mathrm{P}$ & $\mathrm{P}$ & $\mathrm{P}$ & $\mathrm{P}$ & $\mathrm{P}$ & - & - & - \\
\hline V & $\mathrm{P}$ & $\mathrm{P}$ & $\mathrm{P}$ & - & - & - & - & - & - \\
\hline VI & - & - & - & - & - & - & - & - & - \\
\hline VII & - & - & - & - & - & - & $P$ & $\mathrm{P}$ & $\mathrm{P}$ \\
\hline VIII & $\mathrm{P}$ & $\mathrm{N}$ & $\mathrm{P}$ & - & - & - & $\mathrm{P}$ & $\mathrm{P}$ & $\mathrm{P}$ \\
\hline IX & - & - & - & - & - & - & $\mathrm{P}$ & $\mathrm{P}$ & $\mathrm{P}$ \\
\hline$X$ & - & - & - & $\mathrm{P}$ & $P$ & $P$ & - & - & - \\
\hline
\end{tabular}

$\mathrm{A}$ - care; $\mathrm{B}$ - freedom of movement; $\mathrm{C}$ - lighting in premises

Source: Regional Veterinary Inspectorate in Ropczyce

Data from table 3 and 4 show that relevant care is ensured for animals. The observation proves that animals were maintained in the conditions which did not pose any threat to animals, neither in the form of injuries nor suffering. Additionally, based on the farm documentation, it was stated that persons who maintain animals had suitable professional education. Observations in the farm during visits enabled to determine the health condition of animals which did not show any negligence. Also the condition of limbs and hooves gave no raise to concern. During a veterinary control, a special pressure was placed on ensuring a suitable access to water, since it is necessary to ensure animals' welfare. No permanent access to water was reported in six farms. In agricultural farms III and VII despite previous inspection, no automatic drinking bowls were installed until 2013. Among all investigated farms, only three farms were equipped with a separate place for maintaining sick animals quarantined. During another inspection, the same infringements were reported in farms VI and VII.

\section{Statements and conclusions}

The obtained results indicate the improvement of conditions in which dairy cattle is maintained in the controlled farms. Since 2008 to 2013 the monitored farms accepted recommendations of the Veterinary Inspectorate and introduced necessary changes and obtained a positive final evaluation in further controls. Farms IV and V were not controlled in 2008-2010. The first review protocols concerned an animal treatment register and the manner of storing and application of medicines. Positive opinions in protocols showed an increasing trend to 2010 and then a decreasing trend was reported. Protocols with a negative opinion were written (5 protocols). During 68 (2008-2013) visits, no final protocols were made. Further reports concerned such subjects as evaluation of care over animals, freedom of movement and the aspect of lighting in premises where animals were kept. 
72 protocols with a positive opinion were prepared within 6 years. Based on the controls which were made, it may be stated that in 2008-2009 no infringements in maintaining production farms took place. Farm received a positive grade to 2012. Since 2010, a higher number of farms indicated for another control were reported. After control was made in ten farms in 2008-1013, minimal infringements related to standards of maintaining production documentation, were reported. The Coordinated Veterinary Inspection Program did not evaluate all production farms in Podkarpackie Voivodeship. The research is justified based on the relevant economic value in the region, impact of improvement of care with regard to animal health and dairy production development.

\section{Acknowledgements}

The authors would like to express their gratitude to the Main Veterinary Inspectorate in Ropczyce and owners of dairy farms for participation in this research.

\section{References}

Adamczyk, K., Gil, Z., Szarek, J. (2013). Długowieczność miarą dobrostanu bydła. Mat. konf. XXI Szkoły Zimowej Hodowców Bydła w Zakopanem, 102-108.

Adamczyk, K., Gil Z. (2014): Ocena poziomu dobrostanu bydła mlecznego na podstawie wskaźników behawioralnych. Wiadomości Zootechniczne, 2, 43-49.

Fulwider, W. K., Grandin, T., Rollin, B. E., Engle, T. E., Dalsted, N. L., Lamm, W. D. (2008). Survey of dairy management practices on one hundred thirteen north central and northeastern United States dairies. Journal of. Dairy Science. 91, 1686-1692.

Grodzki, H. (2011). Metody chowu i hodowli bydła. Warszawa, Wydawnictwo SGGW. ISBN 978-837583-284

Jagusiak, W., Żarnecki, A., Morek-Kopeć, M., Topolski, P., Krychowski, T. (2014). Modyfikacja indeksu Produkcja Funkcjonalność (PF). Referat XXII Szkoły Zimowej Hodowców Bydła w Zakopanem.

Kołacz, R., Dobrzański, Z. (2006). Higiena i dobrostan zwierząt gospodarskich. Wydawnictwo Akademii Rolniczej we Wrocławiu. ISBN 83-60574-02-2

Kołacz, R., Bodak, E. (1999). Dobrostan zwierząt i kryteria jego oceny. Medycyna Weterynaryjna, $3,147-154$

Rollin, B.E. (2004). Animal agriculture and emerging social ethics for mammals. Journal of Animal. Science. 82, 955-964.

Sapp, S.G., Arnot, J., Fallon, T., Fleck, D., Soorholtz, M., Sutton-Vermeulen, J. J., Wilson, H.. (2009). Consumer trust in the U.S. food system: An examination of the recreancy theorem. Rural Sociol. 74, 525-545.

Ziętara, W. (2013). Opłacalność produkcji mleka w zależności od wybranych czynników. Mat. Konf. XXI Szkoty Zimowej Hodowców Bydla w Zakopanem, 109-123.

Rozporządzenie 1, (2010). Rozporządzenie Ministra Rolnictwa i Rozwoju Wsi w sprawie minimalnych warunków utrzymywania gatunków zwierząt gospodarskich innych niż te, dla których normy ochrony zostały określone w przepisach Unii Europejskiej z dnia 28 czerwca 2010 r., Dz.U. Nr 116, poz. 778.

Rozporządzenie 2, (2010). Rozporządzenie Ministra Rolnictwa i Rozwoju Wsi w sprawie wymagań i sposobu postępowania przy utrzymywaniu gatunków zwierząt gospodarskich, dla których normy ochrony zostały określone w przepisach Unii Europejskiej z dnia 15 lutego 2010r. (Instrukcja Głównego Lekarza Weterynarii z dnia 23 sierpnia 2010r.), Dz.U. Nr 56, poz. 344.

SPIWET- Protokoły SPIWET - Powiatowy Inspektorat Weterynarii w Ropczycach www.giw.pl. 
Evaluation of the dairy...

\title{
OCENA DOBROSTANU BYDLA MLECZNEGO NA PODSTAWIE WYNIKÓW PROTOKOLU SPIWET (SKOORDYNOWANY PROGRAM INSPEKCJI WETERY NARYJNEJ) W WOJEWÓDZTWIE PODKARPACKIM
}

\begin{abstract}
Streszczenie. Produkcja bydła mlecznego pełni istotną rolę w rozwoju województwa podkarpackiego. Postęp tej gałęzi produkcji, może zależeć od wsparcia produkcji mlecznej, które jest udzielane po podjęciu odpowiedniego rodzaju działań. Celem badania było określenie zmian w poziomie dobrostanu zwierząt produkcyjnych, ocena praktyk w hodowli bydła mlecznego w powiecie ropczyckosędziszowskim. Wykorzystano dokumentację hodowlaną gospodarstw i protokoły kontroli SPIWet (Skoordynowany Program Inspekcji Weterynaryjnej), zgodnie z rozporządzeniem (1) Ministra Rolnictwa i Rozwoju Wsi, z dnia 28 czerwca 2010 r., w sprawie minimalnych warunków utrzymania gatunków zwierząt gospodarskich. Do osiągnięcia tego celu wykorzystano 10 stad produkcyjnych krów mlecznych $(\mathrm{n}=240)$ i jałówek $(\mathrm{n}=101)$, produkujących $\geq 10200 \mathrm{~kg}$ mleka za laktację. Obserwacja produkcji mlecznej odbywała się podczas indywidualnych wizyt w gospodarstwach. Wywiady przeprowadzono z pracownikami gospodarstw, przy wykorzystaniu odpowiednio przygotowanych protokołów kontroli weterynaryjnej - SPIWet. Wyniki kontroli uzyskano na podstawie opinii respondentów z instytucji kontrolujących, takich jak: Agencja Restrukturyzacji i Modernizacji Rolnictwa, Rejonowy Urząd Weterynarii oraz pokrewne organy certyfikowane.
\end{abstract}

Słowa kluczowe: produkcja mleka, województwo podkarpackie, protokół weterynaryjny SPIWET, dobrostan 